\title{
On the Fish World
}

\section{Bill Marshall}

Today I visited Gloria in the Royal Women's Hospital. She's just had a baby. A little girl called Megan. It was so tiny. Tiny little hands and feet. And it yawned a lot. Gloria said that the baby 'voiced in mind communication' at her. She said that she could hear 'Military Intelligence voicing' through the baby. I asked her if she told her psychiatrist this. Gloria said no, the psychiatrist never says anything in response about the voices, so why bother? Gloria also said that she wasn't sure if the father of the baby was Donald or Mario. When she was in Park View psychiatric hospital last year, she'd been screwing both of them. Gloria reassured me that I couldn't be the father since she was already pregnant when we'd had sex that time behind the chapel in Park View. This was a relief. I didn't want the responsibility of a child. We went out onto the balcony. I had one cigarette. Gloria had three. Her fingers were a dirty brown from too much nicotine. Gloria told me that the social worker had pressured her into having the baby adopted out. Her parents didn't want her to keep the baby either. They were Seventh Day Adventists or something.I asked Gloria if a baby would cramp her style. She said that discos and nightclubs weren't her thing anymore and the baby would give her empty life some meaning. I didn't argue with her...

I think about my time on the Fish World. I gaze into the frothy, detergent sea as I wander aimlessly along the Black Beach. I am sad and damaged. My heart is as empty as a beggar's hand. The Fish Men descend onto the dirty beach and talk of war and wastage. I can't catch the intricacies of the Fish Men's chatter, their grammar difficult and destructive. You can see them-the Sharks, the Piranhas, the Flatheads—with their blatguns and 
their switchblades, threatening the innocent bystanders with ugly sweeps of their truncated fins...

I had a few beers with Donald at the Royal Oak. Donald's shrink prescribed a new medication for him, Respiridone or similar. He says that it makes him impotent. He can't maintain a hard-on. Donald slammed his pot of beer on the bar and snarled, 'That fucking psychiatrist! How dare she mess with my libido! How would she like it if I cauterized her cunt?' It goes with the territory of being a schizo, the loopy yet patronizing psychiatrists, zealously peddling the anti-psychotic medication. They couldn't care less about the side effects. As if to say 'This won't hurt a bit- I won't feel a thing...'

Donald is like me in that he sleeps until $4 \mathrm{pm}$ or so each day. We connect at the pub or at Ju-Ju's, the local Drop in Centre for the mentally ill. I don't like to visit Donald's flat. He chain-smokes marijuana in joints rolled with chop-chop tobacco. Smoking grass aggravates my psychosis. I flip out and hallucinate wildly. It's like being possessed by an evil demon urging me to go berserk and commit mass murder. It scares me witless and shitless...

The Fish World is dying. The effluent of disease and decay bubbles in the canal that threads its way like a tapeworm through the festering bowels of the city ...

Saw Mario last night at Ju-Ju's. It was the Thursday dinner-roast beef and vegies—only $\$ 2$. Sure beats Maggi prawn-flavored two-minute noodles, or a Big Mac and fries and medium Coke from McDonald's. I told Mario about Gloria's baby. Mario sneered and said, 'Gloria? She's a hooker to thilf!' He stuffed half a roast potato in his mouth and mumbled, 'Have you been rooting anything lately?' Before I could answer, Mario noticed Sharlene, an obese schizophrenic in her mid-twenties. 'Look at the tits on that slut,' he said as he slurped from his cup of tea, 'What a bush-pig she is. Still, I'd love to give the whore a brutal reaming with my pork sword.' Mario cackled insanely, then choked on his food. He spluttered uncontrollably, his eyes bulging, tears running down his face...

A vision of the oceans of Earth superimposed on the cesspool seas of the Fish World. Rusty cans, shredded pieces of styrofoam, used condoms, orange peel and last week's newspapers float about on the brown water, washed ashore by the monotonous lapping waves...

Lying in bed listening to Fox FM. My watch has died and I'm not sure 


\section{Bill Marshall}

of the exact time. Around 11.30pm? Didn't get out of bed till $5 \mathrm{pm}$ today. Watched Wheel of Fortune and The Price is Right. Had a wank. Last night I dreamt that I was masturbating and my cock fell off. I put it in my mouth. Mario has some porno magazines and one of them depicts a young guy sucking himself off. 'Self Sufficiency' he calls it ... .

The newspapers with desperate, stale stories blare their sodden headlines to the indifferent Fish Men. The beach is littered with jagged, broken beer bottles and the yellow bones of decayed beings - Half Men, Half Fish. The stench is the oily waft of garbage sautéed in urine ...

Went to see Gloria at her place today. When I arrived Gloria let me in the door, she was very glad to see me. Once I got into the loungeroom, there was Donald, stark naked drying himself off after a shower. His cock was shriveled like the tiny stub of a carrot. Gloria had told Mario that Donald has a tiny cock and now I had ocular proof.Although there are some things best left unknown. Gloria told me that Human Services had taken the baby into custody. She didn't seem to be upset about losing the baby. Later, Gloria said that she had been raped in her sleep. I asked her who had raped her. She didn't know. But she had seen a black BMW outside in the street and was fairly certain that the driver of the BMW was the rapist...

Here are the towers and turrets of the Metropolis of the Fish Men. Ogres of architecture designed and built that town. In the rancid red light district I see the bars and the brothels where the Mermen and the Fish Chicks hustle for sex. It is a sight for sore and sorry eyes ...

I rang Mario last night. He was very sulky over the phone. He complained about his lack of regular sex. Mario wants an intelligent woman who can 'entertain' him, as well as satisfy his sexual needs. He calls a fuck an 'empty'. He used to call it a 'pump'. Mario reckons that he used to say to his psychiatrist halfway through their session, 'I'm due for my four o'clock pump.' Mario is big on 'information', insisting that he gives women 'good information'. He wants a young woman in her early twenties, as older women have been 'mind-fucked' by life and aren't receptive to his 'information'.

Beyond the suburbs of the city are the petrochemical refineries where the mud puppies yelp and whine on the tainted mudflats. I see the corroded tubes, pipes and hoses that twist and slither like frozen metallic serpents into the core of the refinery. The contorted outlet towering above 
the chemical tanks flares with excess methane that flickers and waves in the winter wind. Welcome to the outer suburbs of the brainstem (the nogo zone) of the Fish Folk, the Ragnarok, the Gotterdammerung, the final defeat of the forces of Light on the Fish World ...

Tonight I ate a tin of Edgell Baby Beets, and a tin of Payless Creamed Corn. Later I ate two Weet-Bix with milk. I've taken my medication. Time for bed... 